J. Reddy Kambam MD, Winston C. V. Parris MD, John J. Franks MD, B. V. Rama Sastry PH D, Rebecca Naukan Bs, Bradley E. Smith MD

\title{
The inhibitory effect of metoclopramide on plasma cholinesterase activity
}

similar to that of procainamide. ${ }^{3}$ We demonstrated

The in vitro effect of metoclopramide on plasma cholinesterase (PCHE) activity was st died o investigate a mechamism for metoclopramide-induced pralongation of succinylcholine action. The mean PCHE af the control samples was $0.86 \pm 0.02$ unit $\cdot \mathrm{m}^{-1}$. PCHE activity in the presence of metoclopramide, at concentrations of $0.05,0.10,0.50,1.0,2.5$ and $5.0 \mu \mathrm{g} \cdot \mathrm{mt}^{-1}$, was reduced to $0.78 \pm 0.02,0.69 \pm 0.04,0.50 \pm 0.03,0.39 \pm$ $0.02,0.24 \pm 0.01$ and $0.15 \pm 0.01$ unit $\cdot \mathrm{ml}^{-1}$, respectively. Our data demonstrated that PCHE activity was significantly de. pressed by metoclopramide at all concentrations studied $(p<$ $0.001)$. Our data also show that the concentration of metoctopramide required to inhibit 50 per cent of PCHE activity $\left(I_{50}\right)$ was $0.8 \mu \mathrm{g} \mathrm{ml}^{-1}\left(2.4 \times 10^{-6} \mathrm{M}\right)$. We recommend caution when succinylcholine and or ester type local anaesrhetics are adminisiered to patients who are also receiving metoclopramide, especially in high doses.

Metoclopramide is one of the most commonly used drugs in the perioperative period. It is especially used by anaesthetists as an antiemetic and to facilitate gastric emptying, thus reducing the risks of aspiration. ' Metoclopramide is also used frequently in the preoperative period by radiologists to aid in radiological examination of the stomach and small intestine. ${ }^{2}$

The chemical structure of metoclopramide is very

\section{Key words}

PHARMACOLOGY: metoclopramide; ENZYMFS: plasma cholinesterase (PCHE), pseudocholinesterase.

From the Departments of Anesthesiology and Pharmacology (BVRS), Vanderbilt University Medical Center, Nashville, Tennessee.

Address correspondente to: J. R. Kambam, MD, Depart ment of Anesthesjology, Vanderbilt University Mcdical Center, Nashville, Tennessee 37232.

Supported by the Study Center for Ancsthesia Toxicology. Yanderbilt University.

Presented at the International Anesthesia Research Socicty, 1988 Congress, San Diego, California. recently the inhibitory effect of procainamide on PCHE activity. ${ }^{4}$ We have also observed prolongation of succinylcholine action in patients receiving metoclopramide suggesting the possibility of depressed PCHE activity. Many patients with a full stomach who undergo regional anaesthesia for emergency surgery receive metoclopramide preoperatively. It may be important for anaesthetists to know the effect of metoclopramide on PCHE activity, especially when they use multiple doses of succinylcholine and/or ester type local anaesthetics in patients receiving metoclopramide. Therefore, we studied the effect of metoclopramide on PCHE activity.

\section{Methods}

With the prior approval of our Institutional Review Board for the Protection of Human Subjects, we included 12 healthy American Society of Anesthesiologists (ASA) physical status I and II patients (ages 25-40, both sexes). Informed consent was obtained from all patients. Ten $\mathrm{ml}$ of venous blood was drawn into a heparinized syringe from each patient. The plasma was immediately separated and stored in a refrigerator at $4^{\circ} \mathrm{C}$ and used within five days for cholinesterase assay. A kinetic method described by Zapf $e t$ al. was used in the determination of PCHE activity and dibucaine numbers (DN). ${ }^{5}$

The reaction mixture contained 1-naphthyl acetate as substrate in phosphate buffer with a pH of 7.50. The total volume of reaction mixture was $3 \mathrm{ml}$. Metoclopramide was added in vitro to the reaction mixture to give a final concentration of $0.05,0.1,0.5,1.0,2.5$, and 5.0 $\mu \mathrm{g} \cdot \mathrm{ml}^{-1}$. After determining a baseline absorbance at 321 nm in a Beckman Model 24 recording spectrophotometer, the reaction was started with the addition of $100 \mu \mathrm{mol}$ of plasma. The absorbance change was recorded and PCHE activity was expressed as units $\cdot \mathrm{ml}^{-1}$ of plasma. One unit corresponds to the liberation of $1 \mu \mathrm{mol}$ of naphthol per minute under conditions of assay.

In addition to linear regression analysis, data were analyzed for statistical significance using a randomized block analysis of variance within treatment levels and multiple comparison testing by the Dunnett's test was 


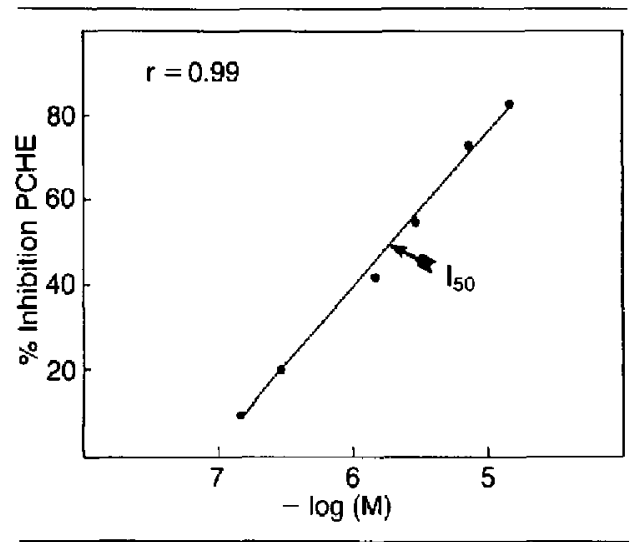

FIGURE Inhibitory effect of metoclopramide on plasma cholinesterase activity (PCHE) $\left(\mathrm{I}_{50}=0.8 \mu \mathrm{g} \cdot \mathrm{m}^{-\mathrm{t}}\right.$ or $2.4 \times 10^{-6} \mathrm{M}$ )

used to compare the drug effects against the control. A difference was considered significant if $\mathrm{p}<0.05$.

\section{Results}

Results are shown in the Table. All the values reported were the average means of duplicate determinations of plasma cholinesterase activity. The mean PCHE activity of all the plasma samples was $0.86 \pm 0.02$ units $\cdot \mathrm{ml}^{-1}$. PCHE activity in the presence of metoclopramide at concentrations of $0.05,0.1,0.5,1.0,2.5$, and 5.0 $\mu \mathrm{g} \cdot \mathrm{ml}^{-1}$ was $0.78 \pm 0.02,0.69 \pm 0.04,0.50 \pm 0.03$, $0.39 \pm 0.02,0.24 \pm 0.01$ and $0.15 \pm 0.01$ units $\cdot \mathrm{ml}^{-1}$, respectively. There was $10,20,42,55,73$ and 83 per cent depression of PCHE activity in the presence of metoclopramide at concentrations of $0.05,0.1,0.5,1.0,2.5$ and $5.0 \mu \mathrm{g} \cdot \mathrm{ml}^{-1}$, respectively. The Figure shows a plot of per cent inhibition of PCHE activity against plasma metoclopramide concentrations. Linear correlation is evident, as indicated by a correlation coefficient $(R)$ of 0.99 . The

TABLE Effect of metoclopramide (MCP) on plasma cholinesterase (PCHE) activity

\begin{tabular}{lll}
\hline$M C P$ & $\begin{array}{l}P C H E \text { Activity } \\
\text { units*m! } \\
\mu g \cdot \text { I }^{-1}\end{array}$ & \\
\hline 0 (control) & $0.86 \pm 0.02$ & - \\
0.05 & $0.78 \pm 0.02^{*}$ & 10 \\
0.10 & $0.69 \pm 0.04^{*}$ & 20 \\
0.50 & $0.50 \pm 0.03^{*}$ & 42 \\
1.00 & $0.39 \pm 0.02^{*}$ & 55 \\
2.50 & $0.24 \pm 0.0 L^{*}$ & 73 \\
5.00 & $0.15 \pm 0.01^{*}$ & 83 \\
\hline
\end{tabular}

$*_{n}=12 ; p<0.001$ (randomized block analysis of yariance) significance of difference from control, $p<0.01$ (Dunnett's test). concentration of metoclopramide required to inhibit $50 \%$ of PCHE activity $\left(\mathbf{I}_{50}\right)$ was found to be $0.8 \mu \mathrm{g} \cdot \mathrm{ml}^{-1}$, or $2.4 \times 10^{-6} \mathrm{M}$.

A randomized block analysis of variance within treatment levels indicated a significant drug effect $(p<$ $0.001)$. A Dunnett's test clearly demonstrated a statistical difference of all treatment levels from the control $(\mathrm{p}<$ 0.01 ).

\section{Discussion}

Metoclopramide (4-amino 5-chloro-N [2-(diethyl amino) ethyl] 2-methoxy benzamide monohydrochloride monohydrate) and procainamide ( $\mathrm{P}$-umino-N [2-(diethyl amino) ethyl] benzamide monohydrochloride) possess very similar chemical structures. ${ }^{3,5}$ We have previously shown that procainamide, an antiarrhythmic drug, inhibits plasma cholinesterase significantly. ${ }^{4}$ Unlike procainamide, metoclopramide has no known antiarrhythmic properties. Like the phenothiazines, meroclopramide produces sedation and occasionally may cause extrapyramidal reactions. Some phenothiazines are also known to inhibit the PCHE activity. ${ }^{8}$

Metoclopramide is being used increasingly by clinicians for the control of nausea and vomiting associated with narcotic analgesic therapy, radiation therapy, chemotherapy, pregnancy, and surgery and anaesthesia.? Metoclopramide in doses of $10-20 \mathrm{mg}$ is used by anaesthetists to facilitate gastric emptying in the preoperative period. A $10 \mathrm{mg}$ dose in adult patients weighing $50-70 \mathrm{~kg}$ gives a peak plasma concentration of up to 0.14 $\mu \mathrm{g} \cdot \mathrm{ml}^{-1} .^{8}$ A dose of $1-3 \mathrm{mg} \cdot \mathrm{kg}^{-1}$ of metoclopramide has been used for chemotherapy induced nausea and vomiting, and doses up to $1000 \mathrm{mg}$ per day have been tried as an antipsychotic agent. ${ }^{9.10}$ Peak plasma concentrations after administration of these high doses of metoclopramide bave not been studied. We believe one should use caution when succinylcholine is administered in these patients especially in those who receive high doses of metoclopramide.

PCHE is a glycoprotein produced mainly in the liver and is responsible for the metabolism of the depolarizing muscle relaxant, succinylcholine, and all ester type local anaesthetics. Pregnancy is associated with a significant decrease in PCHE activity. ${ }^{11}$ Metoclopramide has proved efficacious in the treatment of yomiting and reflux esophagitis associated with pregnancy. ${ }^{12,13}$ Since both pregnancy and the administration of metoclopramide are associated with a decrease in PCHE activity, one should use caution when succinylcholine and/or ester type local anaesthetics are administered in pregnant patients who are also receiving metoclopramide.

Some of the other side effects of metoclopramide that are of particular interest to anaesthesiologists include 
hypotension, hypertensive crisis especially in patients with pheochromocy toma, arrhythmias, drowsiness, interference with absorption of orally administered drugs, and extrapyramidal symptoms. ${ }^{9,14-20}$

In conclusion, our present study demonstrated that metoclopramide has a significant inhibitory effect on PCHE activity when tested in vitro. Our data also show that the concentration of metoclopramide required to inhibit 50 per cent of PCHE activity $\left(I_{50}\right)$ was 0.8 $\mu \mathrm{g} \cdot \mathrm{ml}^{-1}$. We recommend that neuromuscular paralysis be monitored with a peripheral nerve stimulator in patients receiving metoclopramide and succinylcholine. In addition, we suggest the combination of metoclopramide and ester type of local anaesthetics be avoided in pregnant patients and others, who already have diminished PCHE activity.

\section{References}

1 Cooke RD, Comyn DJ, Ball BW. Prevention of postoperative nausca and vomiting by domperidone. A double blind randomized study using domperidone, metoclopramide and a placebo. South African Med J 1979; 56: 827-9.

2 Pajewski M. Eshchar J, Manor A. Visualization of the small intestine by double contrast. Clinical Radiol 1975; 26: 491-3,

3 Harringron RA, Hamilton CW, Brogden RN, Linkewich $J A$, Romankiewicz JA, Heel RC. Metoclopramide, an up-date review of its pharmacological properties and clinical use. Drugs 1983; $25 ; 454-71$.

4 Kambam JR, Naukam RJ, Sastry BVR. The effect of procainamide on plasma cholinesterase activity. Can J Anaesth 1987; 34: 579-81.

5 Zapf PW, Coghlan CHM. A kinetic method for the estimation of pseudncholinesterase using naphthyl acetate substrate. Clin Chim Acta 1974; 43: 237-42.

6 Erdos EG, Baart N, Shanor SP, Foldes FF. The inhibitor effect of chlorpromazine and chlorpromazine sulfoxide on human cholinesterases. Arc Int Pharmacodyn Ther 1958; 117: 163-8.

7 Harrington RA, Hamilton CW, Brogden RN, Linkewich $J A$, Ronankiewicz $J A$, Heel $R C$. Metoclopramide, an up-dale review of its pharmacological properties and clinical use. Drugs 1983; 25: 470-1.

8 Batemn DN, Kahn C, Davies DS. Concentration effect studies with oral metoclopramide. Br J Clin Pharnucol 1979; 8: 179-82.

9 Gralla RJ, Itri LM, Pisko SE. Squillante AE, Kelsen DP. Antiemetic efficacy of high dose metoclopramide: Randomized trials with placebo and prochlorperazine in patients with chemotherapy induced nausea and romiting. N Engl J Med 1981; 305: 905-49.

10 Stanley $M$, Lautin A, Rotrosen J. Gershon S, Kleinberg
$D$. Antipsychotic efficacy of a drug lacking potency in receptor models. Psychopharmacology 1980; 71: 219-25.

11 Kambain JR, Mouton S, Entman S. Sastry BVR, Smish $B E$. Effect of preedlampsit on plasma cholinesterase activity. Can J Anaesth 1987; 34: 509-11.

12 Singh MS, Lean TH. The use of metoclopramide in hyperemesis gravidarum. Proceedings of the Obstetrical and Gynaecological Society, Singapore 1970, 1: 43.

13 Brack-Utne JG, Dow TGB, Welman S, Dimopoulor GE, Moshal MG. The effect of metoclopramide on the lower esophageal sphincter in late pregnancy. Anaesth Intensive Care 1978; 6: 26-9.

14 Park GR. Hypotension following metoclopramide administration during hypotensive anacsthesia for intracranial aneury5m. Br J Anaesth 1978; 50: 1268-9.

15 Pegg MS. Hypotension following metoclopramide injection. Anaesthesia 1980; 35: 615-7.

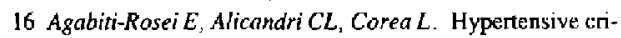
sis in patients with phacochromocytoma given metoclopramide. Lancet 1977; 1: 600-2.

17 Shaklai $M$, Pinkhas J, DeVries A. Metoclopramide and cardiac arrhythmia. Br Med J 1974; 2: 385-6.

18 Schulze $H J$, Winkler $J W$. A serious incidence after IV injection of cerucal. Deutsche Gesundheitswesen 1978; 33: $131-4$.

19 Harrington RA, Hamilton CW, Brogden RN, Linkewich JA, Romankiewicz JA, Heel RC. Metoclopramide, on up-date review of its pharmacological propertics and clinical use. Drugs 1983; 25: 494-5.

20 Bright-Asare $P$, El-bassoussi $M$. Cimetidine, metoclopramide, or placebo in the treatment of symptomatic gastroesophageal reflux. J Clin Gastroenterol 1980; 2: 149-56.

\section{Résumę}

L'effet in vitro de la métoclopramide sur lactivité de la cholinestérase plasmatique (PCHE) a ćté étudié afin d'investiguer le mécanisme de la prolongation de l'action de la succinyl. choline induite par la métoclopramide. La valeur moyenne des échantillons de contrôle de PCHE était de $0.86 \pm 0.02$ unités'ml ${ }^{-1}$. L'activité du PCHE en présence de métoclopramide à des concentrations de $0.05,0.10,0.50,1.0 .2 .5$ et $5.0 \mu \mathrm{g} \cdot \mathrm{ml}^{-1}$, a été réduite à $0.78 \pm 0.02,0.69 \pm 0.04,0.50 \pm 0.03,0.39 \pm 0.02$, $0.24 \pm 0.01$ el $0.15 \pm 0.07$ unités $\cdot \mathrm{mi}^{-1}$ respectivement. Nos données ont démontré que l'activité de la PCHE érait siznificativement diminuée par la métoctopramide d toutes des concentrations étudiées ( $p<0.001$ ). Nos données on aussi démontré que la concentration de métoclopramide requise afin d' inhiber 50 pour cent de l'activité de la $P C H E\left(I_{50}\right)$ était de $0.8 \mu \mathrm{g} \cdot \mathrm{ml}^{-1}$ $\left(2.4 \times 10^{-6} \mathrm{M}\right)$. On recommande la précaution quand la succinylcholine ou anesthesigue local rype ester est administré aux patients qui reçoivent aussi lo métociopramide. spécialement à hautes doses. 